\title{
VARIABILITY IN MACRONUTRIENT COMPOSITION OF WEED SEEDS
}

\author{
LEHOCZKY, É. ${ }^{1}-$ FILEP, T. ${ }^{1 *}-$ MAZSU, N. ${ }^{1}-$ KAMUTI, M. ${ }^{1}-$ GYŐRI, Z. ${ }^{2}$ \\ ${ }^{I}$ Institute for Soil Science and Agricultural Chemistry, Centre for Agricultural Research, \\ Hungarian Academy of Sciences, \\ 1022 Budapest Herman Ottó Str. 15., Hungary \\ ${ }^{2}$ Institute of Human Nutrition, University of Debrecen, 4032 Debrecen, Egyetem tér 1., Hungary \\ *Corresponding author \\ e-mail: filept@ rissac.hu \\ (Received $19^{\text {th }}$ Oct 2015; accepted $11^{\text {th }}$ Apr 2016)
}

\begin{abstract}
The analysis of the element composition of weed seeds and shoots could provide new data for their biological and ecological assessment. In the present study, seed samples of 30 weed species from different plant families were analysed for macronutrients $(\mathrm{K}, \mathrm{Ca}, \mathrm{Mg}, \mathrm{N}, \mathrm{P}, \mathrm{S})$ and high variability was found. There was a considerable difference in the $\mathrm{N}$ content of weed seeds, with the highest value for Asclepias syriaca and the lowest for Xanthium spinosum. The macroelement ratio also exhibited a wide range of values, e.g. the $\mathrm{N}$ to $\mathrm{S}$ ratio varied from 0.2 to 14.2. When crop seed data were compared to those of weed seeds from the same family, the $\mathrm{K}, \mathrm{Ca}, \mathrm{Mg}, \mathrm{P}$ and $\mathrm{S}$ concentrations in weed seeds were found to be significantly higher in many cases. There were significant differences both in the macroelement concentrations and, in some cases, in the nutrient ratios of weed seeds from different plant families. Significant differences were found for $\mathrm{K}, \mathrm{Mg}, \mathrm{P}$ and $\mathrm{S}$, and for the $\mathrm{N} / \mathrm{S}$ and $\mathrm{Ca} / \mathrm{P}$ ratios. This was confirmed by PCA, which illustrated not only differences between weed species, but also the fact that weed plants from the same family formed groups.
\end{abstract}

Keywords: weed seeds; macroelement composition; plant families; diversity

\section{Introduction}

In agricultural systems there is generally a prolonged time gap between two cropping cycles, which poses a potential risk of nutrient losses. Weeds, however, may preserve residual moisture and early rains, and could also fulfil the task of conserving nutrients during the fallow period (Promsakha Na Sakonnakhon et al., 2006; Lehoczky et al., 2012). Weeds may not only fix nutrients, but may also contribute to the nutrient supply of crops in the following growing season. The composition of plant residues has a great influence on how they decay and what nutrients are released from them. Palm et al. (2001) showed marked differences in the quality of residues from different plant families, e.g. leguminous plants release accumulated $\mathrm{N}$ more rapidly. Hence, the composition of the weed plants may have a great impact on nutrient cycling in arable soils. Although numerous studies have been carried out to determine the $\mathrm{N}$ content, amino acids and protein content in weed seeds (Friedman and Levin, 1989; Oderinde and Tairu, 1989; Friedman, 1996), limited information is available on the concentrations and ratios of macroelements $(\mathrm{K}, \mathrm{Ca}, \mathrm{Mg}, \mathrm{P}$ and $\mathrm{S})$.

Weeds reduce crop yields by competing for water, nutrients, space and light (Lehoczky et al., 1995; Lehoczky et al., 2005; Wang et al., 2007). Losses in crop yield caused by weeds are well documented in many studies (Akobundu, 1987; Swanton et al., 1993; Oerke and Dehne, 2004; Lehoczky et al., 2009; 2013b), leading to the conclusion that there is a need for effective weed management programmes. To 
establish such programmes, accurate information is needed on the weed flora, including the distribution, abundance and phenology of weed species and the biodiversity of weed communities (Frick and Thomas, 1992; Lehoczky et al., 2014a, b). Additionally, these data may also be valuable for understanding the dynamics of weed communities and for creating higher biodiversity on arable land (Andreasen and Skovgaard, 2009).

The uptake and accumulation of nutrients in plants depend on their genetic properties and thus on the species and the family (Singh et al., 2003; Györi et al., 2014). Consequently, it would be worth clarifying how weed families affect macroelement accumulation and revealing differences in the rates of accumulation between families. A systematic assessment of the nutrient concentrations in weed seeds, based on weed families, has not yet been carried out.

Among cereal crops, winter wheat and maize are most affected by summer weeds in Hungary (Ujvárosi, 1973). The cover percentage of the top ten weed species in Hungary was Ambrosia artemisiifolia L. (5.3\%), Echinochloa crus-galli (L.) P. B. (4.2\%), Chenopodium album L. (3.7\%), Cirsium arvense (L.) Scop. (1.8\%), Setaria pumila (Poir.) Roem. \& Schult. (1.6\%), Convolvulus arvensis L. (1.5\%), Amaranthus retroflexus L. (1.4\%), Tripleurospermum inodorum (L.) Sch. Bip. (1.1 \%), Datura stramonium L. (1.0\%) and Panicum miliaceum L. (1.0 \%) during the 2007-2008 period (Novák et al., 2009).

The present study investigated the macronutrient composition of 30 seed samples of 30 weed species collected from sites with similar environmental conditions in Hungary. The objectives were (i) to determine the nutrient $(\mathrm{N}, \mathrm{P}, \mathrm{K}, \mathrm{Ca}, \mathrm{Mg}, \mathrm{S})$ contents in 30 weed seeds from 12 weed families, (ii) to evaluate the potential of weed seeds to conserve nutrients compared to crops, (iii) to show the influence of the weed family on the element contents, and (iv) to evaluate the diversity of weed species based on nutrient content of seeds using principal component analysis.

\section{Materials and methods}

\section{Study area}

The survey area was on cultivated land in Keszthely (Zala County, Hungary) with an average annual precipitation of $678 \pm 134 \mathrm{~mm}$ (Debreczeni and Németh, 2009). The soil type was Eutric Cambisol, according to the FAO classification (FAO 1998). The $\mathrm{pH}_{(\mathrm{KCl})}$ of the top $30 \mathrm{~cm}$ soil layer was 6.8 , with $1.9 \%$ organic matter content and $0.4 \% \mathrm{CaCO}_{3}$ content. The texture of the soil was loam. The most common crops were wheat, maize, barley, rape and sunflower.

\section{Plant sampling procedure}

Weed samples were taken from July to the end of October by sampling mature weed plants. In the laboratory, weed seeds were manually separated and ground. Prior to the digestion and ICP analysis, the seed samples was washed with distilled water. The 30 weed species investigated are listed in Table 1.

\section{Laboratory analysis}

The soil $\mathrm{pH}$ was measured in 1:2.5 soil:1 $\mathrm{M} \mathrm{KCl}$ suspensions 12 hours after mixing (MSZ-08-0206/2:1978). The organic matter content was determined by the modified Walkley-Black method (Walkley and Black, 1934), which involved digesting the soil 
organic matter with $5 \% \quad \mathrm{~K}_{2} \mathrm{Cr}_{2} \mathrm{O}_{7}$ and cc. $\mathrm{H}_{2} \mathrm{SO}_{4}$ and analysing the colour of the suspension, which was related to the organic matter content of the samples, colorimetrically (MSZ-08-0452:1980). Particle-size distribution was determined by the pipette method. The soil:water suspension was mixed in a sedimentation cylinder, then sampled with a pipette to collect particles of a given size (MSZ-08-0215:1978). The $\mathrm{CaCO}_{3}$ content was measured with a calcimeter; the soil was mixed with diluted $\mathrm{HCl}$ solution and the volume of $\mathrm{CO}_{2}$ released was determined (MSZ-08-0206/2:1978).

Table 1. The weed species investigated

\begin{tabular}{|c|c|c|c|c|c|}
\hline No. & Name & $\begin{array}{l}\text { EPPO } \\
\text { code }\end{array}$ & Family & $\begin{array}{c}\text { Raunkiær's } \\
\text { life form }\end{array}$ & $\begin{array}{l}\text { Ujvárosi's } \\
\text { life form }\end{array}$ \\
\hline 1 & Amaranthus albus L. & AMAAL & Amaranthaceae & $\mathrm{Th}$ & $\mathrm{T}_{4}$ \\
\hline 2 & Amaranthus retroflexus L. & AMARE & Amaranthaceae & Th & $\mathrm{T}_{4}$ \\
\hline 3 & Asclepias syriaca L. & ASCSY & Asclepiadaceae & G & $\mathrm{G}_{3}$ \\
\hline 4 & Ambrosia artemisiifolia $\mathrm{L}$. & AMBEL & Asteraceae & Th & $\mathrm{T}_{4}$ \\
\hline 5 & Cirsium arvense (L.) Scop. & CIRAR & Asteraceae & $\mathrm{G}$ & $\mathrm{G}_{3}$ \\
\hline 6 & Erigeron canadensis L. & ERICA & Asteraceae & Th & $\mathrm{T}_{4}$ \\
\hline 7 & Galinsoga parviflora Cav. & GASPA & Asteraceae & Th & $\mathrm{T}_{4}$ \\
\hline 8 & Tripleurospermum inodorum (L.) Sch.Bip. & MATIN & Asteraceae & $\mathrm{TH} / \mathrm{H}$ & $\mathrm{T}_{4}$ \\
\hline 9 & Senecio vulgaris $\mathrm{L}$ & SENVU & Asteraceae & $\mathrm{Th}$ & $\mathrm{T}_{1}$ \\
\hline 10 & Xanthium spinosum $\mathrm{L}$. & XANSP & Asteraceae & Th & $\mathrm{T}_{4}$ \\
\hline 11 & Xanthium strumarium L. & XANST & Asteraceae & Th & $\mathrm{T}_{4}$ \\
\hline 12 & Sinapis arvensis L. & SINAR & Brassicaceae & Th & $\mathrm{T}_{3}$ \\
\hline 13 & Stellaria media (L.) Vill. & STEME & Caryophyllaceae & Th & $\mathrm{T}_{1}$ \\
\hline 14 & Chenopodium album L. & CHEAL & Chenopodiaceae & Th & $\mathrm{T}_{4}$ \\
\hline 15 & Chenopodium hybridum L. & CHEHY & Chenopodiaceae & $\mathrm{Th}$ & $\mathrm{T}_{4}$ \\
\hline 16 & Calystegia sepium (L.) R. Br. & CALSE & Convolvulaceae & $(\mathrm{G}) \mathrm{H}$ & $\mathrm{G}_{1}$ \\
\hline 17 & Convolvulus arvensis L. & CONAR & Convolvulaceae & $\mathrm{G}$ & $\mathrm{G}_{3}$ \\
\hline 18 & Abutilon theophrasti Medic. & ABUTH & Malvaceae & Th & $\mathrm{T}_{4}$ \\
\hline 19 & Veronica hederifolia L. & VERHE & Scrophulariaceae & Th & $\mathrm{T}_{1}$ \\
\hline 20 & Cynodon dactylon (L.) Pers. & CYNDA & Poaceae & $\mathrm{G}(\mathrm{H})$ & $\mathrm{G}_{1}$ \\
\hline 21 & Echinochloa crus-galli (L.) P. Beauv. & ECHCG & Poaceae & $\mathrm{Th}$ & $\mathrm{T}_{4}$ \\
\hline 22 & Panicum miliaceum $\mathrm{L}$. & PANMI & Poaceae & $\mathrm{Th}$ & $\mathrm{T}_{4}$ \\
\hline 23 & Sorghum halepense (L.) Pers. & SORHA & Poaceae & $\mathrm{G}(\mathrm{H})$ & $\mathrm{G}_{1}$ \\
\hline 24 & Fallopia convolvulus (L.) Á. Löve & POLCO & Polygonaceae & $\mathrm{Th}$ & $\mathrm{T}_{4}$ \\
\hline 25 & Persicaria lapathifolia (L.) Delarbre & POLLA & Polygonaceae & $\mathrm{H}$ & $\mathrm{T}_{4}$ \\
\hline 26 & Polygonum aviculare $\mathrm{L}$. & POLAV & Polygonaceae & Th & $\mathrm{T}_{4}$ \\
\hline 27 & Persicaria maculosa Gray & POLPE & Polygonaceae & Th & $\mathrm{T}_{4}$ \\
\hline 28 & Consolida regalis Gray & CNSRE & Ranunculaceae & Th & $\mathrm{T}_{2}$ \\
\hline 29 & Datura stramonium L. & DATST & Solanaceae & Th & $\mathrm{T}_{4}$ \\
\hline 30 & Solanum nigrum L. & SOLNI & Solanaceae & Th & $\mathrm{T}_{4}$ \\
\hline
\end{tabular}

Th: therophyta; H: hemikryptophyta; G: kryptophyta; TH: hemitherophyta (Raunkiær, 1934).

${ }^{\mathrm{b}} \mathrm{G}_{1}$ : Geophyta, rhizomatous plants; $\mathrm{G}_{3}$ : Geophyta, perennials with reproductive roots; $\mathrm{T}_{1}$ : Therophyta, winter annuals, ripen seeds in spring; $\mathrm{T}_{2}$ : Therophyta, winter annuals, ripen seeds in summer; $\mathrm{T}_{3}$ : Therophyta, summer annuals, emergence in spring, ripen in summer; $\mathrm{T}_{4}$ : Therophyta, summer annuals, emergence in summer, ripen in autumn (Ujvárosi, 1973).

The $\mathrm{K}, \mathrm{Ca}, \mathrm{Mg}, \mathrm{P}$ and $\mathrm{S}$ concentrations in the weed seeds was determined with the ICP-MS method after microwave Teflon bomb digestion with cc. $\mathrm{HNO}_{3}+\mathrm{H}_{2} \mathrm{O}_{2}$ (Kovács et al., 1996). The $\mathrm{N}$ c ontent of the weed seeds was analysed with an Elementar VarioMax instrument (Hanau, Germany) based on the Dumas combustion method (Jones, 1992). 


\section{Quality control}

The high purity water $\left(18.2 \mathrm{M} \Omega \mathrm{cm}^{-1}\right)$ used for the preparation of all blanks, standards and sample solutions was obtained from a Millipore water purification system (Millipore, France). The instrument was calibrated using multi-element standard solutions prepared in $1 \%$ nitric acid by mixing and diluting AAS stock solutions of individual elements.

For ICP-MS analysis, each sample was analysed in triplicate, using an external standard (BCR CRM 189 wheat) to assure the accuracy of the whole analytical procedure (Table 2).

Table 2. Results of analysis on certified samples

\begin{tabular}{lcc}
\hline \multicolumn{1}{c}{ Element } & Certified value & Measured value \\
\hline $\mathrm{K}\left(\mathrm{mg} \mathrm{kg}^{-1}\right)$ & $33800 \pm 800^{\mathrm{a}}$ & $32786 \pm 2563$ \\
$\mathrm{Ca}\left(\mathrm{mg} \mathrm{kg}^{-1}\right)$ & $6400 \pm 100$ & $6384 \pm 175$ \\
$\mathrm{Mg}\left(\mathrm{mg} \mathrm{kg}^{-1}\right)$ & $1450 \pm 40$ & $1601 \pm 114.2$ \\
$\mathrm{P}\left(\mathrm{mg} \mathrm{kg}^{-1}\right)$ & $2360 \pm 70$ & $2440 \pm 116.8$ \\
$\mathrm{~S}\left(\mathrm{mg} \mathrm{kg}^{-1}\right)$ & $3160 \pm 40$ & $3308 \pm 112$ \\
${ }^{\mathrm{a}}$ mean \pm standard deviation &
\end{tabular}

\section{Statistical methods}

Analysis of variance (ANOVA) was carried out on the element concentrations in the different weed species and families using SPSS 16.0 software. To evaluate the ranking order of macroelement contents in the plant families, the Duncan pot hoc test was performed at $\mathrm{p}<0.05$, using only families represented by more than one species.

Principal component analysis (PCA) was used to evaluate the diversity of weeds with respect to nutrient content. PCA is a multivariate technique in which new variables (called principal components or PCs) are calculated as linear combinations of the original variables (nutrient concentrations of weed seeds). The PCA was performed using varimax rotation and the PCA scores were displayed as a biplot diagram, which attempts to represent both the observations and variables of multivariate data in the same plot.

\section{Results and Discussion}

\section{Nutrient concentrations and ratios in weed seeds}

Both the whole weed plant and its various parts, including the seeds, can be considered as a nutrient pool for the soil and consequently as a nutrient source for crops grown for human or animal consumption. There is a considerable difference in the $\mathrm{N}$ content of weed seeds, with the highest value for Asclepias syriaca and the lowest for Xanthium spinosum. The S content ranged from $1.3 \mathrm{~g} \mathrm{~kg}^{-1}$ in Persicaria lapathifolia to $17.8 \mathrm{~g} \mathrm{~kg}^{-1}$ in Sinapis arvensis. High variability was found in the K concentration, with the highest value of $20.5 \mathrm{~g} \mathrm{~kg}^{-1}$ in Erigeron canadensis and the lowest value of $2.2 \mathrm{~g} \mathrm{~kg}^{-}$ 1 in Panicum miliaceum (Table 3). The Ca content ranged from $17.4 \mathrm{~g} \mathrm{~kg}^{-1}$ in Polygonum aviculare to only $0.2 \mathrm{~g} \mathrm{~kg}^{-1}$ in Panicum miliaceum. In the case of $\mathrm{Mg}$, there was a moderate variability in the concentrations, from 1.3 to $4.0 \mathrm{~g} \mathrm{~kg}^{-1}$. Five-fold 
differences were revealed for $\mathrm{P}$, with values of $10.2 \mathrm{~g} \mathrm{~kg}^{-1}$ in Abutilon theophrasti and $1.9 \mathrm{~g} \mathrm{~kg}^{-1}$ in Cynodon dactylon.

With respect to element ratios, the $\mathrm{Ca} / \mathrm{P}$ ratio ranged from 0.06 to 7.6 in the weed seeds investigated (Table 3), with the highest value for Polygonum aviculare. The N/S ratio varied from 0.2 to 14.2 , with the highest value for Abutilon theophrasti.

Table 3. Nutrient contents and macroelement ratios in the weed seeds investigated

\begin{tabular}{|c|c|c|c|c|c|c|c|c|c|}
\hline Code $^{a}$ & Family & $\mathbf{N}$ & $\mathbf{P}$ & $\mathbf{K}$ & $\mathbf{C a}$ & Mg & $\mathbf{S}$ & $\mathbf{N} / \mathbf{S}$ & $\mathbf{C a} / \mathbf{P}$ \\
\hline & & \multicolumn{6}{|c|}{$g k^{-1}$} & \multicolumn{2}{|c|}{ ratio } \\
\hline AMAAL & Amaranthaceae & 23.0 & 3.4 & 3.8 & 3.6 & 3.2 & 2.2 & 10.4 & 1.0 \\
\hline AMARE & Amaranthaceae & 25.7 & 5.7 & 5.3 & 3.4 & 3.7 & 2.4 & 10.9 & 0.6 \\
\hline ASCSY & Asclepiadaceae & 58.5 & 7.7 & 7.9 & 3.5 & 4.0 & 4.7 & 12.6 & 0.5 \\
\hline AMBEL & Asteraceae & 44.6 & 7.7 & 9.5 & 4.1 & 3.2 & 4.1 & 10.9 & 0.5 \\
\hline CIRAR & Asteraceae & 22.5 & 6.3 & 6.7 & 6.2 & 2.5 & 2.5 & 9.0 & 1.0 \\
\hline ERICA & Asteraceae & 31.8 & 6.3 & 20.5 & 12.3 & 2.7 & 4.0 & 7.9 & 1.9 \\
\hline GASPA & Asteraceae & 16.1 & 4.0 & 11.1 & 6.8 & 2.1 & 2.4 & 6.6 & 1.7 \\
\hline MATIN & Asteraceae & 27.0 & 6.1 & 11.3 & 3.2 & 2.6 & 2.9 & 9.2 & 0.5 \\
\hline SENVU & Asteraceae & 39.0 & 5.9 & 8.9 & 7.2 & 3.2 & 3.7 & 10.4 & 1.2 \\
\hline XANSP & Asteraceae & 9.9 & 2.7 & 11.8 & 2.6 & 1.7 & 1.7 & 5.9 & 1.0 \\
\hline XANST & Asteraceae & 31.0 & 5.6 & 12.6 & 1.9 & 2.4 & 2.7 & 11.5 & 0.3 \\
\hline SINAR & Brassicaceae & 45.2 & 9.9 & 6.3 & 5.2 & 3.5 & 17.8 & 2.5 & 0.5 \\
\hline STEME & Caryophyllaceae & 27.7 & 4.3 & 3.9 & 2.6 & 2.7 & 2.5 & 11.0 & 0.6 \\
\hline CHEAL & Chenopodiaceae & 24.9 & 4.4 & 8.8 & 2.1 & 2.4 & 2.2 & 11.2 & 0.5 \\
\hline CHEHY & Chenopodiaceae & 20.6 & 3.0 & 11.3 & 1.6 & 2.0 & 2.0 & 10.1 & 0.5 \\
\hline CALSE & Convolvulaceae & 33.9 & 6.5 & 15.7 & 1.2 & 2.9 & 3.0 & 11.2 & 0.2 \\
\hline CONAR & Convolvulaceae & 34.9 & 6.3 & 16.7 & 1.4 & 2.7 & 2.7 & 13.0 & 0.2 \\
\hline ABUTH & Malvaceae & 35.1 & 10.2 & 13.4 & 1.9 & 3.6 & 2.5 & 14.2 & 0.2 \\
\hline CYNDA & Poaceae & 18.6 & 1.9 & 3.5 & 4.7 & 2.6 & 2.2 & 8.6 & 2.4 \\
\hline ECHCG & Poaceae & 19.3 & 5.4 & 5.8 & 2.2 & 3.0 & 2.0 & 9.9 & 0.4 \\
\hline PANMI & Poaceae & 20.9 & 3.5 & 2.2 & 0.2 & 1.2 & 1.9 & 10.9 & 0.1 \\
\hline SORHA & Poaceae & 17.1 & 4.4 & 2.6 & 0.7 & 1.9 & 2.0 & 8.5 & 0.2 \\
\hline POLAV & Polygonaceae & 24.0 & 2.3 & 5.3 & 17.4 & 2.1 & 1.8 & 13.0 & 7.7 \\
\hline POLCO & Polygonaceae & 19.2 & 2.8 & 11.4 & 4.7 & 2.7 & 2.0 & 9.6 & 1.7 \\
\hline POLLA & Polygonaceae & 16.3 & 3.2 & 2.8 & 1.0 & 2.0 & 1.3 & 12.5 & 0.3 \\
\hline POLPE & Polygonaceae & 17.4 & 5.1 & 7.7 & 1.2 & 2.2 & 1.5 & 11.9 & 0.2 \\
\hline CNSRE & Ranunculaceae & 32.2 & 6.6 & 7.2 & 11.4 & 2.9 & 3.4 & 9.6 & 1.7 \\
\hline VERHE & Scrophulariaceae & 20.1 & 4.8 & 5.5 & 2.2 & 1.3 & 2.1 & 9.6 & 0.5 \\
\hline DATST & Solanaceae & 29.1 & 5.9 & 5.4 & 1.1 & 3.1 & 3.2 & 9.1 & 0.2 \\
\hline SOLNI & Solanaceae & 26.0 & 8.8 & 4.1 & 0.9 & 3.9 & 2.6 & 9.9 & 0.1 \\
\hline
\end{tabular}

${ }^{\mathrm{a}}$ The full name of the weeds are in Table 1 .

\section{Comparison of weed data to crop seed concentrations}

To evaluate the nutrient conservation potential of the weeds, the nutrient content of crop species was compared to that of w eed species from the same family. High nutrient contents were determined in the thirty weed seed samples in comparison with crop seed concentrations, as shown in Table 4. Differences in the element concentrations have been reported both for crop seeds (White and Broadley, 2009; Lehoczky et al., 2013a) and for weed seeds, due to a combination of environmental and genetic factors.

In the Poaceae family the potassium concentration in weed seeds was found to be higher than in the seeds of small grain crops. In experiments in Keszthely (Györi, 2009) maize and wheat grains were found to have lower values of $\mathrm{K}$ than those recorded for weed seeds in the present work, despite the differences in species, genotypes and 
environmental conditions. This was particularly true of the very high $\mathrm{K}$ value found in the weed seed Erigeron canadensis $\left(20.0 \mathrm{~g} \mathrm{~kg}^{-1}\right)$. Similar conclusions could be drawn for the Polygonaceae family, while the rest of the families had comparable $\mathrm{K}$ concentrations in weed and crop seeds.

Table 4. Comparison of the nutrient contents of weed seeds and crop seeds from the same family

\begin{tabular}{|c|c|c|c|c|c|c|}
\hline $\mathbf{K}$ & Ca & Mg & $\mathbf{P}$ & $\mathbf{S}$ & \multirow[t]{2}{*}{ Crop } & \multirow[t]{2}{*}{ Family } \\
\hline \multicolumn{5}{|c|}{$g \mathrm{~kg}^{-1}$} & & \\
\hline 5.1 & 0.46 & 1.5 & 3.9 & 1.3 & wheat $^{1}$ & Poaceae \\
\hline 3.0 & 0.4 & 1.5 & 3.2 & 1.5 & wheat $^{2}$ & Poaceae \\
\hline $2.4-3.2$ & $0.01-0.13$ & $0.8-1.6$ & $2.4-4.6$ & $0.97-1.8$ & maize $^{3}$ & Poaceae \\
\hline $3.5 \pm 1.6$ & $1.9 \pm 2.0$ & $2.2 \pm 0.8$ & $3.8 \pm 1.5$ & $2.0 \pm 0.1$ & weeds & Poaceae \\
\hline $15.6 \pm 3.6$ & $6.4 \pm 2.4$ & $5.3 \pm 2.2$ & $4.6 \pm 0.7$ & $3.1 \pm 0.5$ & sunflower $^{4}$ & Asteraceae \\
\hline $11.6 \pm 4.1$ & $5.5 \pm 3.4$ & $2.5 \pm 0.5$ & $5.5 \pm 1.5$ & $3.0 \pm 0.8$ & weeds & Asteraceae \\
\hline 2.4 & 0.30 & 0.92 & 1.3 & 0.47 & buckwheat $^{5}$ & Polygonaceae \\
\hline $0.80-1.3$ & $0.52-0.74$ & $0.50-0.78$ & $1.6-2.4$ & - & buckwheat $^{6}$ & Polygonaceae \\
\hline $6.8 \pm 3.7$ & $6.1 \pm 7.7$ & $2.2 \pm 0.3$ & $3.3 \pm 1.2$ & $1.6 \pm 0.3$ & weeds & Polygonaceae \\
\hline $2.4-6.9$ & $0.01-0.28$ & $0.11-0.38$ & $0.33-1.3$ & - & potato $^{7}$ & Solanaceae \\
\hline 4.1 & 0.09 & 0.21 & 0.62 & - & potato $^{8}$ & Solanaceae \\
\hline $47 \pm 0.9$ & $1.0 \pm 0.1$ & $3.5 \pm 0.6$ & $7.3 \pm 2.0$ & $2.9 \pm 0.4$ & weeds & Solanaceae \\
\hline 8.2 & 3.5 & 2.7 & 5.7 & - & rapeseed $^{9}$ & Brassicaceae \\
\hline 6.3 & 5.2 & 3.5 & 9.9 & 17.8 & weed & Brassicaceae \\
\hline $7.1-7.7$ & $7.4-9.3$ & $4.6-6.8$ & $5.9-6.5$ & - & $\operatorname{amaranth}^{10}$ & Amaranthaceae \\
\hline $4.5 \pm 1.1$ & $3.5 \pm 0.1$ & $3.5 \pm 0.4$ & $4.6 \pm 1.6$ & $2.3 \pm 0.1$ & weeds & Amaranthaceae \\
\hline
\end{tabular}

${ }^{\mathrm{a}}$ Mean \pm standard deviation;

${ }^{1}$ Győri, 2009; ${ }^{2}$ Kádár and Daood, 2001; ${ }^{3}$ Menkir, 2008; ${ }^{4}$ Kötschau et al., 2014; ${ }^{5}$ Vogel-Mikuš et al., 2009; ${ }^{6}$ Peng et al., 2014; ${ }^{7}$ Burlingame et al., 2009; ${ }^{8}$ USDA National Nutrient Database, No: $11365 ;{ }^{9}$ Kádár, 2002; ${ }^{10}$ Haghighi et al., 2012.

The Ca concentrations in weed seeds were found to be an order of magnitude higher than those in crop species from the Poaceae, Polygonaceae and Solanaceae families (Table 4). In the Amaranthaceae, Asteraceae and Brassicaceae families, the Ca content was similar in crop and weed seeds. Some weed species were found to have very high $\mathrm{Ca}$ concentrations, e.g. Erigeron canadensis, Consolida regalis and Polygonum aviculare gave values of $12.3,11.4$ and $17.4 \mathrm{~g} \mathrm{~kg}^{-1} \mathrm{Ca}$, respectively.

Very little variation was detected in the $\mathrm{Mg}$ concentration of the weed seeds, indicating that no weed species have extremely high or low $\mathrm{Mg}$ contents. However, in crop seeds, significant differences were recorded in many cases. For instance, the $\mathrm{Mg}$ content of weed seeds from the Poaceae, Polygonaceae and Solanaceae families was higher than in crop seeds from the same family.

The average $\mathrm{P}$ concentrations in crop seeds ranged from 0.33 to $6.5 \mathrm{~g} \mathrm{~kg}^{-1}$ (Table 4). Among the Solanaceae the crop species (potato) was found to have a significantly lower $\mathrm{P}$ content than the average $\mathrm{P}$ concentration of weed seeds from the same family. Especially high P concentrations were determined for Abutilon theophrasti $\left(11.1 \mathrm{~g} \mathrm{~kg}^{-1}\right)$ and Sinapis arvensis $\left(9.9 \mathrm{~g} \mathrm{~kg}^{-1}\right)$.

Consistently with the well-known fact that plants of the Brassicaceae family have high S concentration due to the mustard oil content of the seeds (Björkman et al., 2011; 
Li et al., 2012), $17.8 \mathrm{~g} \mathrm{~kg}^{-1} \mathrm{~S}$ was detected in Sinapis arvensis. The concentrations in all the weed seeds ranged from 1.4 to $4.6 \mathrm{~g} \mathrm{~kg}^{-1}$, which was higher than the values recorded for the crop species.

In general, all the macroelements investigated had in higher or at least comparable concentrations in the weed seeds. The Ca concentration in particular was found to be much higher in weed seeds than in crop seeds.

\section{Differences in the element contents and ratios between weed seeds of different families}

Among the macroelements significant differences between weed families were found in the concentrations of $\mathrm{P}, \mathrm{K}, \mathrm{Mg}$ and $\mathrm{S}$ (Fig. 1).

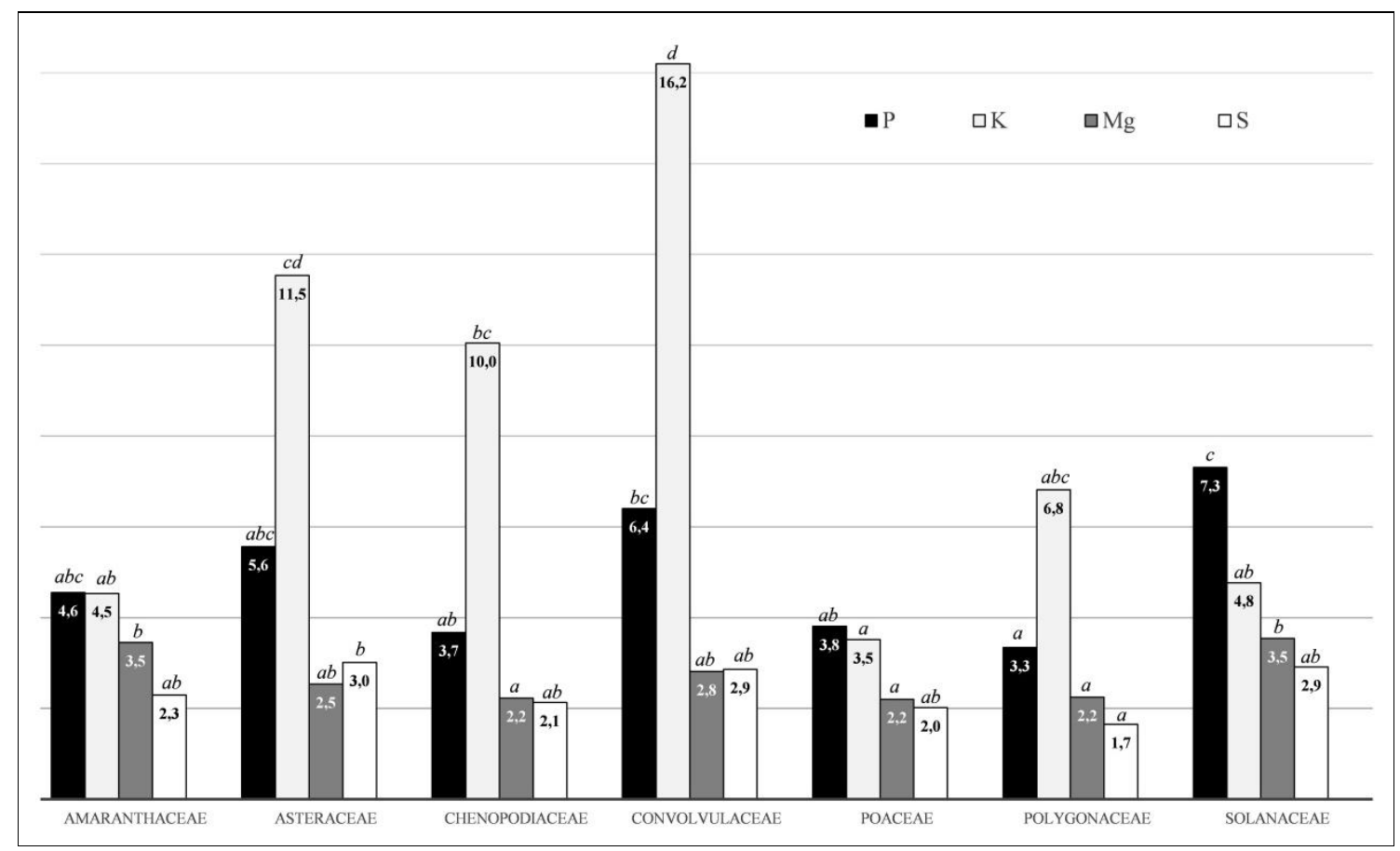

Figure 1. Macronutrient contents in weed seeds from different families ( $a-d$ indicate significant differences within families for the given element at the $5 \%$ level of probability according to Duncan's test)

For K, the following ranking order was found for the weed families from the highest to the lowest K contents: Convolvulaceae > Asteraceae > Chenopodiaceae > Amaranthaceae $=$ Polygonaceae $>$ Poaceae $=$ Solanaceae . Similar orders were found for $\mathrm{P}$ and S, with the highest contents in Asteraceae, Convolvulaceae and Solanaceae, and relatively low concentrations in Polygonaceae, Poaceae and Amaranthaceae. For Mg the ranking order was as follows: Solanaceae $>$ Asteraceae $=$ Amaranthaceae $=$ Convolvulaceae $>$ Chenopodiaceae $=$ Poaceae $=$ Polygonaceae .

Other authors investigating the effect of the family on the element concentrations in weed seeds also reported significant differences in most cases (Tanji and Elgharous, 1998). The fact that individual genotypes may differ in their nutrient demands, uptake ability and nutrient transport within the plant is well documented (Ramage and Williams, 2002; Lovkova et al., 2008; White and Brown, 2010). 
The main factor affecting the concentrations of different elements in a plant appears to be the nutrient requirements of the plant rather than the nutrient supplies in the soil (Markert, 1989). This was confirmed by surveys showing different concentrations of trace and macro-elements in different plants even if they were grown in the same place (Løbersli and Steinnes, 1988; Willey et al., 2005; Lehoczky et al., 2013b).

\section{Evaluation of diversity based on nutrient content of seeds using PCA}

As shown in the previous section, significant variability has been found between weed families with respect to macroelement status. Principal component analysis is another way to reveal the diversity or similarity between weed communities. The factor loadings and score plots obtained using this method are presented for the 30 weed seeds in Table 5 and Figures $2 A$ and $B$.

The first three principal components were found to have eigenvalues $>1$ and accounted for $36.6 \%, 23.6 \%$ and $17.9 \%$ of total variation, respectively, giving a cumulative variance of $78.1 \%$.

Table 5. Factor loadings for the elements analyzed in the weed seed samples

\begin{tabular}{lccc}
\hline & PC1 & PC2 & PC3 \\
\cline { 2 - 4 } $\mathbf{N}$ & $\mathbf{0 . 9 1 4}$ & 0.034 & 0.076 \\
$\mathbf{P}$ & $\mathbf{0 . 8 5 8}$ & -0.260 & 0.206 \\
$\mathbf{K}$ & 0.382 & 0.140 & -0.147 \\
$\mathbf{C a}$ & 0.117 & $\mathbf{0 . 9 6 0}$ & 0.108 \\
$\mathbf{M g}$ & $\mathbf{0 . 8 3 0}$ & -0.059 & 0.049 \\
$\mathbf{S}$ & 0.479 & 0.020 & $\mathbf{0 . 8 1 7}$ \\
$\mathbf{N} / \mathbf{S}$ & 0.194 & -0.026 & $\mathbf{- 0 . 9 2 9}$ \\
$\mathbf{C a} / \mathbf{P}$ & -0.156 & $\mathbf{0 . 9 5 2}$ & -0.070 \\
\hline
\end{tabular}

The first $\mathrm{PC}(\mathrm{PC} 1)$ showed high loadings for $\mathrm{N}, \mathrm{P}$ and $\mathrm{Mg}$, while $\mathrm{PC} 2$ gave high loadings for $\mathrm{Ca}$ and the $\mathrm{Ca} / \mathrm{P}$ ratio and $\mathrm{PC} 3$ for $\mathrm{S}$ and the N/S ratio (shown in bold in Table 5). The high loadings for $\mathrm{N}$ and $\mathrm{P}$ in $\mathrm{PC} 1$ can be attributed to the fact that these elements have similar chemical and consequently biological properties, being non-metal elements. Surprisingly, Mg also made a high contribution to PC1 rather than to PC2, which consists of metal elements, especially Ca.

To visualize the differences and similarities in the nutrient contents of weed species, PC scores were calculated, as displayed on the biplots (Fig. 2A and $2 B$ ) illustrating the patterns of nutritional status in weed seeds. The great differences between the weed species are indicated by the scattered dots plotted for the weed plants. The position of the given weed in the factor space shows the nutritional status of the weeds, e.g. the PC3 value is very high for the Brassiceae due to the high S content (Fig. 2B), while the $\mathrm{PC} 1$ score for the Malvaceae family is indicative of its high content of $\mathrm{N}, \mathrm{P}$ and $\mathrm{Mg}$ (Fig. 2A). 


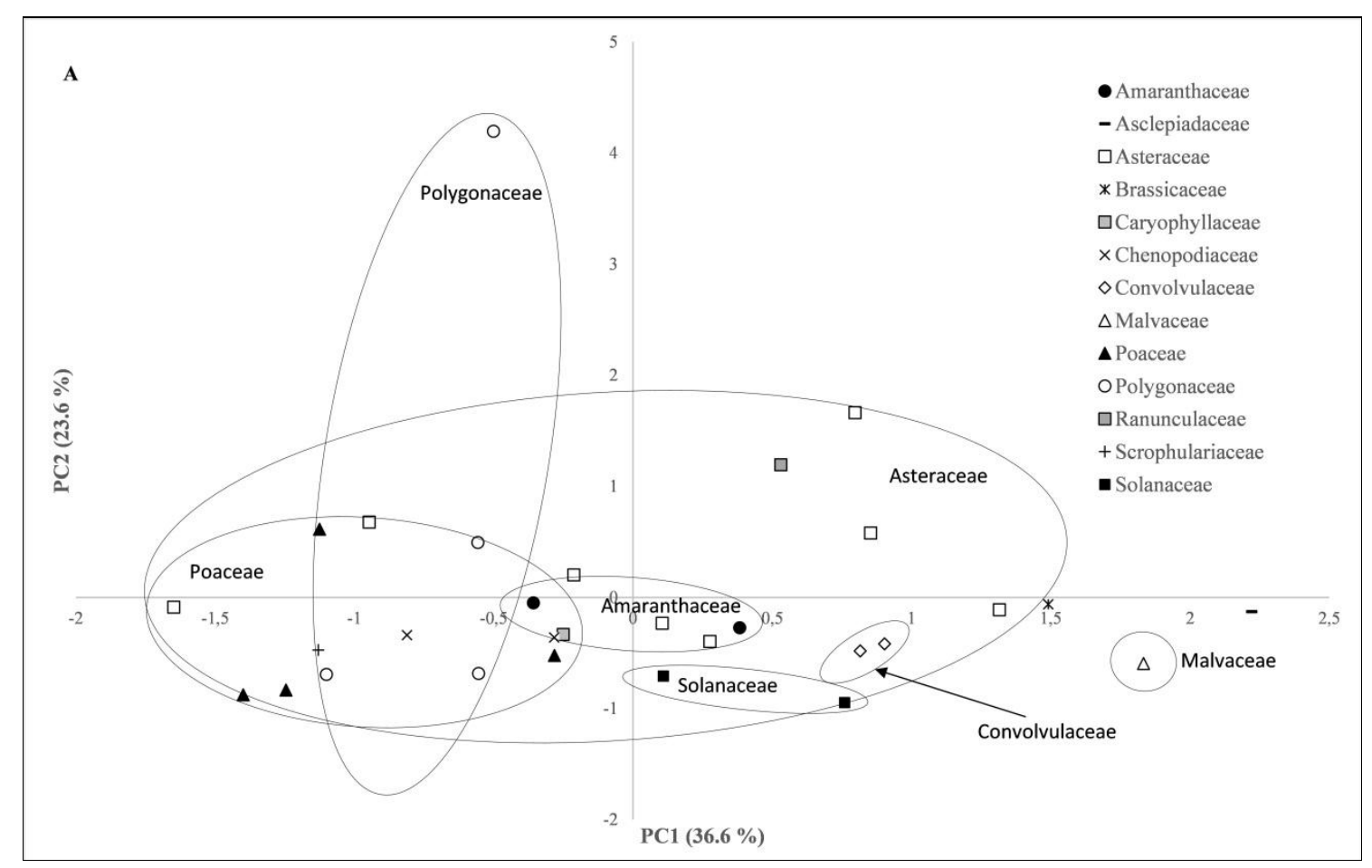

Figure 2A. PCA ordination of weed species investigated (PC1 vs PC2)

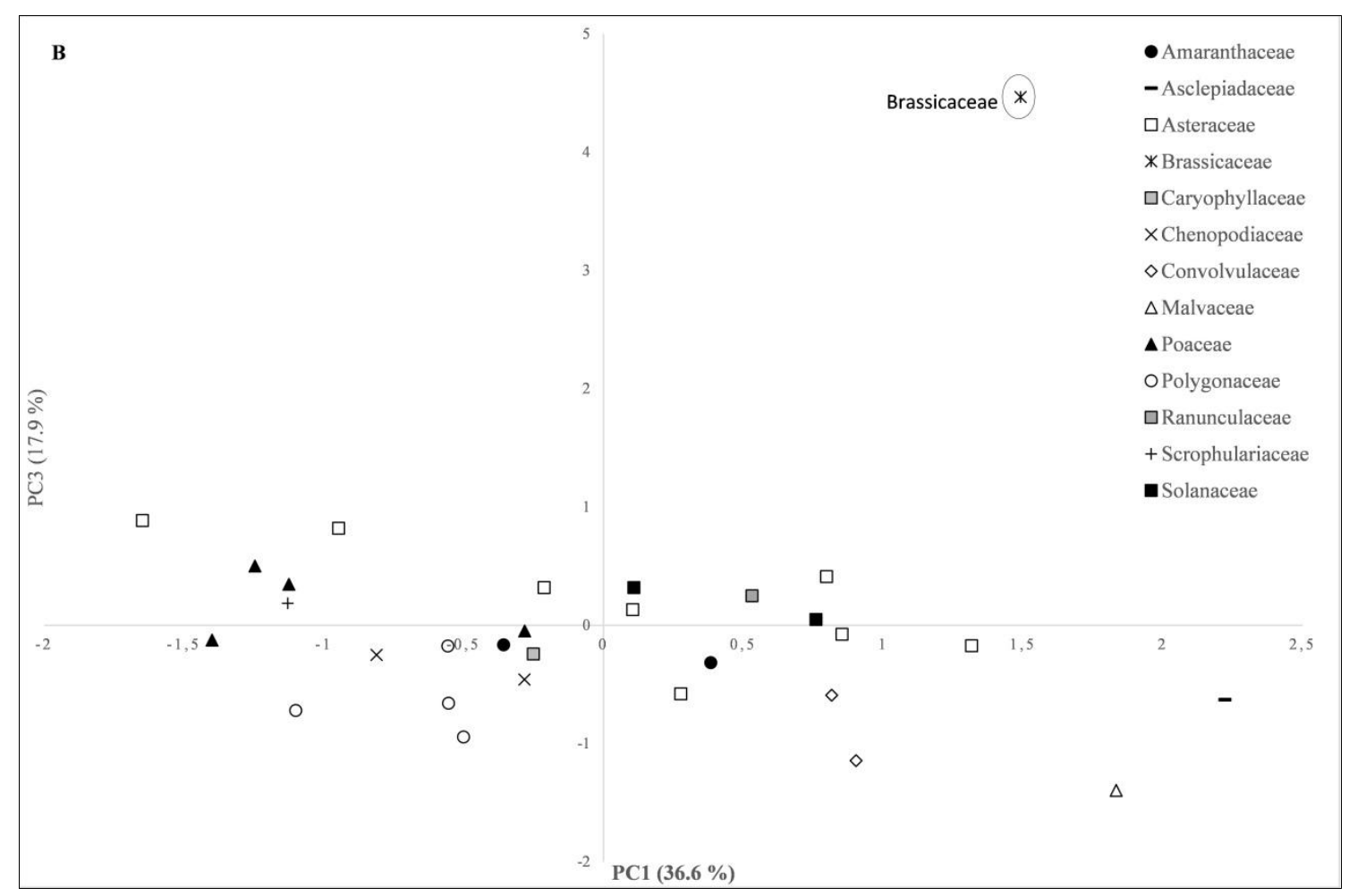

Figure 2B. PCA ordination of weed species investigated (PC1 vs PC3)

Although the points representing the weed samples are very scattered, it is possible to detect groups of weeds that belong to the same family. The Polygonaceae family, for instance, has similar scores on axis $1(-0.5$ to -1$)$, indicating that the common feature of 
this family is the $\mathrm{N}, \mathrm{P}$ and $\mathrm{Mg}$ content. In the case of the Asteraceae, the weed samples had similar PC scores on axis 2, which indicates that the common feature for weeds classified as Asteraceae is the $\mathrm{Ca}$ content. For the other families, there is no clear orientation, implying that they have a mixed type of features. However, the weed families can be separated by their PC scores: the Polygonaceae, Convolvulaceae and Malvaceae can be separated on the basis of $\mathrm{PC1}$, while, as shown earlier, the Brassicaceae differ from the other weed families in terms of PC3.

\section{Conclusions}

Although great variability was observed for the nutrient quantities in weed seeds, the $\mathrm{N}, \mathrm{K}, \mathrm{Ca}, \mathrm{Mg}, \mathrm{P}$ and $\mathrm{S}$ concentrations in weed seeds were significantly higher than those in crop seeds from the same family, indicating that they could help to improve nutrient conservation during the fallow period. However, the variability in the nutrient content must be taken into account when determining the beneficial impact of weeds on the nutritional status of soil-plant systems; e.g. weeds from the Asteraceae family have more potential to conserve $\mathrm{N}$ as they have significantly higher $\mathrm{N}$ content than weeds from the Polygonaceae family.

Differences between weed families were mainly found in the case of macroelement accumulation, and these differences were mainly caused by the genetic diversity of weed species belonging to different families.

Acknowledgement. This project was supported by the Hungarian Scientific Research Fund (K 105789). Authors wish to thank to Dr. Andrea Kovács for $\mathrm{N}$ and $\mathrm{S}$ measurements.

\section{REFERENCES}

[1] Akobundu, I.O. (1987): Weed Science in the Tropics: Principles and Practices. - John Wiley \& Sons Ltd, New York.

[2] Andreasen, C., Skovgaard, I.M. (2009): Crop and soil factors of importance for the distribution of plant species on arable fields in Denmark. - Agriculture, Ecosystems \& Environment 133: 61-67.

[3] Björkman, M., Klingen, I., Birch, A.N.E., Bones, A.M., Bruce, T.J.A., Johansen, T.J., Meadow, R., Mølmann, J., Seljåsen, R., Smart, L.E., Stewart, D. (2011): Phytochemicals of Brassicaceae in plant protection and human health - influences of climate, environment and agronomic practice. - Phytochemistry 72: 538-556.

[4] Burlingame, B., Mouillé, B., Charrondiére, R. (2009): Nutrients, bioactive non-nutrients and anti-nutrients in potatoes. - Journal of Food Composition and Analysis 22: 494-502.

[5] Debreczeni, B-né, Németh, T. (eds.) (2009): Hungarian National Long-term Fertilization Experiment Network (in Hungarian). - Akadémiai Kiadó, Budapest.

[6] Frick, B., Thomas, A.G. (1992): Weed surveys in different tillage systems in south western Ontario field crops. - Canadian Journal of Plant Science 72: 1337-1347.

[7] Friedman, M. (1996): Nutritional value of proteins from different food sources. A review. - Journal of Agricultural and Food Chemistry 44: 6-29.

[8] Friedman, M., Levin, C.E. (1989): Composition of Jimson weed (Datura stramonium) seeds. - Journal of Agricultural and Food Chemistry 37: 998-1005.

[9] Győri, Z., Filep, T., Lehoczky, É. (2014): Trace element content of several weed seeds. Carpathian Journal of Earth And Environmental Sciences 9(2): 251-257 
[10] Györi, Z. (2009): The effect of fertilization on the chemical composition of test plants and quality parameters (in Hungarian). - In: Debreczeni, B-né, Németh, T. (eds.) Hungarian National Long-term Fertilization Experiment Network, Akadémiai Kiadó, Budapest.

[11] Haghighi, M.L., Abbaszadeh, B., Changaei, N. (2012): Variation in macronutrients uptake by two Amaranth varieties planted in two different times. - Annals of Biological Research 3(8): 3949-3951.

[12] Jones, J.B. (1992): Methods of nitrogen determination in soils and plant tissue. Communications in Soil Science and Plant Analysis 19: 493-505.

[13] Kádár, I. (2002): The evaluation of nutrient status of rapeseed (Brassica napus L.) by plant analysis (in Hungarian). - Agrokémia és Talajtan 52(3-4): 395-416.

[14] Kádár, I., Daood, H. (2001): The effect of microelement-charge on wheat on calcareous chernozem soil (in Hungarian). - Agrokémia és Talajtan 50: 353-370.

[15] Kötschau, A., Büchel, G., Einax, J.W., Meißner, R., von Tümpling, W., Merten, D. (2014): Element pattern recognition and classification in sunflower (Helianthus annuus) grown on contaminated and non contaminated soil. - Microchemical Journal 114: 164174.

[16] Kovács, B., Győri, Z., Prokisch, J., Loch, J., Dániel, P. (1996): A study of plant sample preparation and inductively coupled plasma emission spectrometry parameters. Communications in Soil Science and Plant Analysis 27: 1177-1198.

[17] Lehoczk,y É., Reisinger, P., Kömíves, T. (2005): Loss of nutrients caused by excessive weediness at the early stage of maize vegetation period. - Communications in Soil Science and Plant Analysis 36(4-6): 415-422.

[18] Lehoczky, É., Busznyák, J., Gólya, G., Pálmai, O. (2012): Green water - Ambrosia artemisiifolia L. on winter wheat stubble. - Növénytermelés 61(3): 259-262.

[19] Lehoczky, É., Gólya, G., Radimszky, L., Riczu, P., Tamás, J. (2013a): Study ont he weed flora in maize in connection with nutrient supply. - Növénytermelés 62: 147-150.

[20] Lehoczky, É., Kamuti, M., Mazsu, N., Radimszky, L., Sándor, R. (2014b): Composition, density and dominance of weeds in maize at different nutrient supply levels. Növénytermelés 63(1): 287-290.

[21] Lehoczky, É., Kamuti, M., Mazsu, N., Tamás, J., Sáringer-Kenyeres, D., Gólya, G. (2014a): Influence of NPK fertilization on weed flora in maize field. - Agrokémia és Talajtan 63(1): 139-148.

[22] Lehoczky, É., Kismányoky, A., Tóth, V., Németh, T. (2009): Weediness and the nutrient uptake by weeds in relation to the soil tillage. - Communications in Soil Science and Plant Analysis 40(1-6): 871-878.

[23] Lehoczky, É., Márton, L., Nagy, P. (2013b): Competition for nutrients between coldtolerant maize and weeds. - Communications in Soil Science and Plant Analysis 44(1-4): 526-534.

[24] Li, Y., Hussain, N., Zhang, L., Chen, X., Ali, E., Jiang, L. (2013): Correlations between Tocopherol and Fatty Acid Components in Germplasm Collections of Brassica Oilseeds. - Journal of Agricultural and Food Chemistry 61: 34-40.

[25] Løbersli, E.S., Steinnes, E. (1988): Metal uptake in plants from a birch forest area near a copper smelter in Norway. - Water, Air, \& Soil Pollution 37: 25-39.

[26] Lovkova, M.Ya, Buzuk, G.N., Sokolova, S.M. (2008): Genetic aspects of the interrelation between alkaloids and chemical elements in Atropa belladonna L. and Glaucium flavum Crantz. plants. - Prikladnaia biokhimiia i mikrobiologiia 44: 459-462.

[27] Markert, B. (1989): Multi-element analysis in ecosystems: basic conditions for representative sampling of plant materials. - Fresenius' Zeitschrift für Analytische Chemie 335: 562-565.

[28] Menkir, A. (2008): Genetic variation for grain mineral content in tropical-adapted maize inbred lines. - Food Chemistry 110: 454-464.

[29] MSZ-08-0206/2:1978 Evaluation of some chemical properties of the soil. Laboratory tests. ( $\mathrm{pH}$ value, phenolphtaleine alkalinity expressed in soda, all water soluble salts, 
hydrolite (y1-value) and exchanging acidity (y2-value). (In Hungarian) - Hungarian Standard Association, Budapest.

[30] MSZ-08-0215:1978: Determination of the cation adsorption capacity of the soil. Modified Mechlich technique. (In Hungarian) - Hungarian Standard Association, Budapest.

[31] MSZ-08-0452:1980 Use of high-capacity analyser systems for soils analyses. Quantitative determination of the organic carbon content of the soil on Contiflo analyzer system. (In Hungarian) - Hungarian Standard Association, Budapest.

[32] Novák, R., Dancza, I., Szentey, L., Karamán, J. (2009): Weeds of arable lands in Hungary. Fifth weed survey of Hungary (2007-2008) (in Hungarian). - FVM, Budapest.

[33] Oderinde, R.A., Tairu, A.O. (1989): Utilisation of yellow nutsedge tuber for composite flour. - Pakistan Journal of Scientific and Industrial Research 32: 570-573.

[34] Oerke, E.C., Dehne, H.W. (2004): Safeguarding production - losses in major crops and the role of crop protection. - Crop Protection 23: 275-285.

[35] Palm, C.A., Gachego, C., Delve, R., Cadisch, G., Giller, K.E. (2001): Organic inputs for soil fertility management in tropical agroecosystems: application of an organic resource database. - Agriculture, Ecosystems \& Environment 83: 27-42.

[36] Peng, L., Huang, Y., Liu, Y., Zhang, Z., Lu, L., Zhao, G. (2014): Evaluation of essential and toxic element concentrations in buckwheat by experimental and chemometric approaches. - Journal of Integrative Agriculture 13(8): 1691-1698.

[37] Promsakha Na Sakonnakhon, S., Cadisch, G., Toomsan, B., Vityakon, P., Limpinuntana, V., Patanothai, A. (2006): Weeds - friend or foe? The role of weed composition on stover nutrient recycling efficiency. - Field Crops Research 97: 239-247.

[38] Ramage, C.M., Williams, R.R. (2002): Mineral nutrition and plant morphogenesis. - In Vitro Cellular \& Developmental Biology 38: 116-124.

[39] Raunkiær, C. (1934): The life forms of plants and statistical plant geography. - Calderon Press, Oxford.

[40] Singh, O.V., Labana, S., Pandey, G., Budhiraja, R., Jain, R.K. (2003): Phytoremediation an overview of metallic ion decontamination from soil. - Applied Microbiology and Biotechnology 61: 405-412.

[41] Swanton, C.J., Harker, K.N., Anderson, R.L. (1993): Crop losses due to weeds in Canada. - Weed Technololgy 7: 537-542.

[42] Tanji, A. Elgharous, M. (1998): A survey of mineral composition of weed seeds. - Weed Research 38: 79-86.

[43] Ujvárosi, M. (1973): Weeds. (in Hungarian) - Mezőgazdasági Kiadó, Budapest.

[44] Vogel-Mikuš, K., Pelicon, P., Vavpetic, P., Kreft, I., Regvar, M. (2009): Elemental analysis of edible grains by micro-PIXE: Common buckwheat case study. - Nuclear Instruments and Methods in Physics Research 267: 2884-2889.

[45] Walkley, A., Black, I.A. (1934): An examination of the Degtjareff method for determining organic carbon in soils: Effect of variations in digestion conditions and of inorganic soil constituents. - Soil Science 63: 251-263.

[46] Wang, S., Duan, L., Li, J., Tian, X., Li, Z. (2007): UV-B radiation increases paraquat tolerance of two broad leaved and two grass weeds in relation to changes in herbicide absorption and photosynthesis. - Weed Research 47(2): 122-128.

[47] White, P.J., Broadley, M.R. (2009): Biofortification of crops with seven mineral elements often lacking in human diets - iron, zinc, copper, calcium, magnesium, selenium and iodine. - New Phytologist 182: 49-84.

[48] White, P.J., Brown, P.H. (2010): Plant nutrition for sustainable development and global health. - Annals of Botany 105: 1073-1080.

[49] Willey, N.J., Tang, S., Watt, N.R. (2005): Predicting inter-taxa differences in plant uptake of cesium-134/137. - Journal of Environmental Quality 34: 1478-1489. 